\title{
Antimycobacterial activity of certain mangrove plants against multi-drug resistant Mycobacterium tuberculosis
}

\author{
Amudha', Prabuseenivasan², Vanaja Kumar² \\ ${ }^{1}$ Department of Biotechnology, Jaya College of Arts and Science, Tirunindravur, Chennai, India, ${ }^{2}$ Department of Bacteriology, National Institute \\ for Research in Tuberculosis (ICMR), Chetput, Chennai, Tamil Nadu, India
}

\section{A B S T R A C T}

Objectives: The present study was conducted aiming to identify a potent mangrove plant against Mycobacterium tuberculosis using rapid method, luciferase reporter phage (LRP) assay. Methods: Seven mangrove plants viz., Ceriops decandra, Aegiceras corniculatum, Excoecaria agollacha,Avicennia officinalis, Rhizophora mucronata, Suaeda monoica and Sesuvium portulacastrum were collected from Pichavaram mangrove forest in the east coast of, Tamil Nadu. Hexane and methanol extracts were obtained and antimycobacterial activity was done by LRP assay at the concentration of $500 \mu \mathrm{g} / \mathrm{ml}$. Mycobacterial strains viz. reference strain $M$. tuberculosis $\mathrm{H}_{37} \mathrm{Rv}$ and two clinical isolates of $M$. tuberculosis, one sensitive and the other resistant to Streptomycin, Isoniazid, Rifampicin and Ethambutol used for this study. Results: Methanol extract of $E$. agollacha showed maximum antimycobacterial activity followed by $A$. corniculatum and $A$. officinalis at $500 \mu \mathrm{g} / \mathrm{ml}$ concentration. The remaining four plants (Suaeda monoica, Sesuvium portulacastrum, R. mucronata and C. decandra) showed less or no activity. However, hexane extracts of all the tested plants failed to inhibit the mycobacterial strains. Conclusions: Among the seven plants tested, E. agollacha was found to have better antiTB activity. Further studies based on bioassay guided fractionation and phytochemical analysis may useful to identify the potent antimycobacterial molecule(s) from this mangrove plant.

Key words: Antimycobacterial activity, Mangrove plants, MDR tuberculosis and LRP assay

\section{INTRODUCTION}

Mycobacterium tuberculosis is a highly infectious disease that spreads through air. The rate of mortality caused by tuberculosis is much higher than any other bacterial infections; around 30\% of the AIDS related deaths are due to tuberculosis. ${ }^{1}$ India is the highest tuberculosis burden country accounting for one fifth $(21 \%)$ of the global incidence. ${ }^{2}$ At present, because of uncontrolled application of anti-tuberculosis drugs, there is an increasing prevalence of both MDR and XDR strains. ${ }^{3}$ So there is an urgent need to discover new antibiotics against drug resistance $M$. tuberculosis.

Nearly $80 \%$ of the world population depends upon medicines from plant sources. ${ }^{4}$ It is already proved that plants and other natural products is template for the development of new scaffolds of drugs. ${ }^{5}$ The primary benefits of using plant derived medicines are that they are relatively safer than synthetic derivatives, offering profound therapeutic benefits and more affordable treatment. India is one of the few countries in the world that has unique wealth of medicinal plants and vast traditional knowledge of use of herbal medicines for cure of various diseases. Like other terrestrial plants, many mangrove plants have ethnopharmacological relevance and have also been exploited by the local people in the search for remedies for various ailments.

Flora of mangrove forests is unique from others in that their habitat extends along the border where the fresh and sea water merge. Therefore, unlike common terrestrial plants, they can withstand high salt concentration, can remain submerged in water, and maintain an efficient 
nutrient retention mechanism. ${ }^{6}$ However, only a few of the mangrove plants are investigated for their antimycobacterial activity, due to lack of adequate information available about their uses and the difficulty in screening methodology of atimycobacterial activity. Plants often produce secondary metabolites under stressful conditions, as the mangrove plants, facing various ecological and environmental stresses, biosynthesis a wide range secondary metabolites of potential medicinal importance. In this regard, the present study was aimed to screen some medicinally important mangrove plant against $M$. tuberculosis using rapid method luciferase reporter phage (LRP) assay.

\section{MATERIALS AND METHODS}

\section{Collection of mangrove plants}

Based on the traditional knowledge and literature survey, seven mangrove plants were collected from Pichavaram mangrove forest, east coast, Tamil Nadu (Table 1). All the collected plants were identified and authenticated in CAS in Marine Biology, Annamalai University, Chidambaram, Tamil Nadu. The collected specimens were shade dried and powdered individually using electric blender. The powdered materials were sequentially extracted with solvent $(1: 5 \mathrm{w} / \mathrm{v})$ such as hexane and methanol. Each extract was filtered and condensed using rotary vacuum evaporator to obtain solvent free residue and these crude extracts were stored in $-20^{\circ} \mathrm{C}$ until use.

\section{Mycobacterial strains}

Three Mycobacterial strains, viz., standard strain of $M$. tuberculosis $\mathrm{H} 37 \mathrm{Rv}$, clinical isolates of $M$. tuberculosis strains resistant to first line antiTB drugs, Streptomycin(S), Isoniazid (H), Rifampicin(R) and Ethambutol(E) and sensitive to SHRE were used for this study. These strains were grown and maintained on Lowenstein Jensen (L-J) medium in the Department of Bacteriology, National

\begin{tabular}{|c|c|c|c|}
\hline S. No. & Botanical name & $\begin{array}{l}\text { Common } \\
\text { name }\end{array}$ & $\begin{array}{l}\text { Medicinal use/ } \\
\text { properties }\end{array}$ \\
\hline 1 & $\begin{array}{l}\text { Aegiceras } \\
\text { corniculatum }\end{array}$ & Narikkandal & $\begin{array}{l}\text { Asthma, Diabetes } \\
\text { and Rheumatism }\end{array}$ \\
\hline 2 & $\begin{array}{l}\text { Avicennia } \\
\text { officinalis }\end{array}$ & Venkandal, & $\begin{array}{l}\text { Diuretic, Hepatitis, } \\
\text { and Leprosy }\end{array}$ \\
\hline 3 & $\begin{array}{l}\text { Ceriops } \\
\text { decandra }\end{array}$ & Chiru kandal & $\begin{array}{l}\text { Hepatitis, and } \\
\text { Ulcers }\end{array}$ \\
\hline 4 & $\begin{array}{l}\text { Excoecaria } \\
\text { agollacha, }\end{array}$ & Thillai & $\begin{array}{l}\text { Leprosy and } \\
\text { Epilepsy }\end{array}$ \\
\hline 5 & $\begin{array}{l}\text { Rhizophora } \\
\text { mucronata }\end{array}$ & Surapunnai & $\begin{array}{l}\text { Elephantiasis, } \\
\text { Hepatitis and } \\
\text { Febrifuge }\end{array}$ \\
\hline 6 & Suaeda monoica & Umarichedi & Hepatitis \\
\hline 7 & $\begin{array}{l}\text { Sesuvium } \\
\text { portulacastrum }\end{array}$ & Vangaravasi & Hepatitis \\
\hline
\end{tabular}

Institute for Research in Tuberculosis (NIRT- ICMR), Chennai, Tamil Nadu, India.

Antimycobacterial activity using Luciferase Reporter Phage assay

Luciferase reporter phage PhAE129, a D29 derived mycobacteriophage, constructed in the laboratory of W.R. Jacobswas used ${ }^{7}$ in this study and it was propagated with M. smegmatis $\mathrm{mc}^{2} 155$ to get high titer by harvesting with Mycobacteriophage buffer (MP) from lacey plates and stored at $4^{\circ} \mathrm{C}$ until use.

Luciferase reporter phage (LRP) assay was carried out using standard protocol. ${ }^{8}$ Hundred microliter bacterial suspensions equivalent to McFarland \#2 standard were added to $400 \mu \mathrm{l}$ of G7H9 with and without the test compound. For each sample, two sample-free controls and single drug concentration $(500 \mu \mathrm{g} / \mathrm{ml})$ were prepared, and incubated for $72 \mathrm{~h}$ at $37^{\circ} \mathrm{C}$. After incubation, $50 \mu \mathrm{l}$ of the high-titer phage phAE129 and $40 \mu \mathrm{l}$ of $0.1 \mathrm{M} \mathrm{CaCl}_{2}$ were added to all the vials and incubated at $37^{\circ} \mathrm{C}$ for another $4 \mathrm{~h}$. After incubation, $100 \mathrm{ml}$ of the mixture was transferred from each tube into a star tube and equal amount of working D-luciferin $(0.3 \mathrm{mM}$ in $0.05 \mathrm{M}$ sodium citrate buffer, $\mathrm{pH} 4.5$ ) solution was added. The relative light unit (RLU) was measured after 10s of integration in the luminometer (Monolight 2010). The percentage reduction in RLU was calculated for each test sample and compared with the control. Antimycobacterial activity is indicated by fifty percent reduction in relative light units (RLU) in the presence of compound in comparison with compound free control.

\section{Phytochemical screening}

Phytochemical screening for the active crude extract of E. agollacha was performed by standard protocol to find out the presence of phyto-constituents viz., Alkaloids, flavonoids, glycosides, phytosterol, tannins, saponins and volatile oils.., 10

\section{RESULTS}

In the present study, two solvent extracts of seven mangrove plants were screened for antimycobacterial activity against standard strain and two clinical isolates of tuberculosis. The results are presented in Table 2. The methanolic extract of E. agollacha showed maximum antimycobacterial activity against standard strain of $M$. tuberculosis $\mathrm{H}_{37} \mathrm{Rv}(88.95 \%)$, clinical isolate resistant to first line drugs $(70.02 \%)$ and the sensitive strain of $M$. tuberculosis $(82.54 \%)$ followed by $A$. corniculatum and $A$. officinalisat at $500 \mu \mathrm{g} / \mathrm{ml}$ concentration. In other hand $C$. decandra, R. mucronata, $S$. monoica and $S$. portulacastrum exhibited weak or no activity against all three tested strains of $M$. tuberculosis when compared with sample free controls. 


\begin{tabular}{|c|c|c|c|c|c|c|}
\hline \multirow[t]{2}{*}{$\begin{array}{l}\text { Mangrove } \\
\text { plants }\end{array}$} & \multicolumn{2}{|c|}{$\begin{array}{l}\text { M. tuberculosis H37Rv } \\
\text { (Standard strain) }\end{array}$} & \multicolumn{2}{|c|}{$\begin{array}{l}\text { M. tuberculosis isolates } \\
\text { (Resistant to SHRE) }\end{array}$} & \multicolumn{2}{|c|}{$\begin{array}{l}\text { M. tuberculosis isolates } \\
\text { (Sensitive to SHRE) }\end{array}$} \\
\hline & Hexane & Methanol & Hexane & Methanol & Hexane & Methanol \\
\hline A. corniculatum & 0.00 & 66.63 & 34.36 & 54.70 & 15.16 & 64.33 \\
\hline A. officinalis & 43.03 & 61.39 & 11.77 & 51.04 & 47.58 & 73.08 \\
\hline C. decandra & 0.00 & 21.05 & 0.97 & 28.59 & 0.00 & 33.97 \\
\hline E. agollacha & 43.94 & 88.95 & 43.33 & 70.02 & 41.10 & 82.54 \\
\hline R. mucronata & 0.00 & 0.00 & 20.27 & 32.83 & 11.12 & 24.46 \\
\hline S. monoica & 0.00 & 46.42 & 17.30 & 42.50 & 46.52 & 41.81 \\
\hline S. portulacastrum & 0.00 & 43.95 & 0.00 & 38.42 & 17.36 & 49.23 \\
\hline
\end{tabular}

The preliminary phytochemical screening of active methanolic extract of E. agollacha is presented in Table 3. The findings revealed that the plant contains alkaloids, flavonoids, phytosterols, tannins and absence of glycosides, saponins and essential oils. The same observation was made by Dhyanithi et al., $2012^{11}$ and they found the methanol extract of E. agollacha showsignificant antibacterial activity against fish pathogen, Aeromonas bydropbila.

\section{DISCUSSION}

The antimycobaterial activity exhibited by the mangrove plant extracts could be due to the presence of phytochemicals such as, alkaloids, tannins and flavonoids present in the plants. Extracts and products of mangrove plants are used in traditional medicine to treat various diseases for centuries. ${ }^{12}$ The present study indicates that when compared with hexane extracts, the crude methanol extracts showed better inhibition activity against all tested mycobacteria indicating that active ingredients in the plant could be extracted in to methanol. However some plants extracts did not exhibit any activity. This is probably because accumulation of intracellular active ingredients is low or the concentration of the compound used may not be sufficient.

Some of the mangrove plants have been screened earlier for antiviral, antibacterial, antiulcer and anti-inflammatory activity. ${ }^{13}$ In this study, E. agallocha showed maximum antimycobacterial activity among the tested plants. In traditional Thai medicine, the bark and wood of E. agallocha is used to treat flatulence, leprosy and inflammation. ${ }^{14}$ The plant is used to treat sores and stings from marine creatures. Smoke from the bark of E. agallocha is used to treat leprosy and used as purgative and emetic. Boiled oil, from its latex, is applied in rheumatism, leprosy and paralysis. ${ }^{15}$ The plant is being tested for modern medical uses and clinical trials show that the plant may have anti-HIV, anti-cancer, anti-bacterial and anti-viral properties. ${ }^{16}$ Hence in recent years, screening of mangrove plants is being paid more attention to develop novel drugs against pathogens. In this regard further fractionation and structural elucidation of

$\begin{aligned} & \text { Table 3: Preliminary phytochemical screening of } \\
& \text { active methanolic extract of }\end{aligned}$. agallocha
\begin{tabular}{llc} 
S. No. & Phyto-constituents & Methanol extract \\
\hline 1 & Alkaloids & + \\
2 & Glycosides & - \\
3 & Flavonoids & + \\
4 & phytosterols & + \\
5 & Saponins & + \\
6 & Tannins & + \\
7 & Essential oils & - \\
\hline
\end{tabular}

E. agallocha will be worth pursuing and may lead to potential anti-TB agents.

\section{CONCLUSIONS}

Among the seven selected plants, E. agollacha was found to have better anti-TB activity. Further studies based on bioassay guided fractionation and phytochemical analysis may lead to potent antimycobacterial molecule(s) from this mangrove plant.

\section{ACKNOWLEDGEMENT}

Authors are grateful to local people of Pitchavaram for providing the information about mangrove plants and sample collection. The authors are also thankful to Director, NIRT for providing facilities to carry out antimycobacterial activity.

\section{REFERENCES}

1. Grange JM and Zumla A. The global emergency of tuberculosis: what is the cause? J R Soc Promot Health 2002; 122(2): 78-81.

2. RNTCP annual status report, New Delhi. 2001: www.tbc.nic.in/ documents.htm

3. Raviglione M. "XDR-TB: entering the post-antibiotic era?" Int J Tuberc Lung Dis 2006; 10(11): 1185-1187.

4. World Health Organization 2008: www.who.int/mediacentre/ factsheets/fs134/en/

5. Newman D J and Cragg GM. "Natural products as sources of new drugs over the last 25 years." J Nat Prod 2007; 70(3): 461-477. 
6. Alongi DM. Present state and future of the world's mangrove forests. Environ Conserv 2002; 29(3):331-349.

7. Carriere C, Riska PF, Zimhony O, Kriakov J, Bardarov S, Burns $\mathrm{J}$, et al. Conditionally replicating luciferase reporter phages: improved sensitivity for rapid detection and assessment of drug susceptibility of Mycobacterium tuberculosis. J Clin Microbiol 1997; 35: 3232-3239.

8. Sivakumar PM, Seenivasan SP, Kumar V and Doble M. Synthesis, antimycobacterial activity evaluation, and QSAR studies of chalcone derivatives Bioorg. Med. Chem. Lett 2007; 17(6): 1695-1700.

9. Trease GE and Evans WC. A Text Book of Pharmacognosy. ELSB/ Bailliere Tindal, Oxford; 1987.

10. Harborne JB. Phytochemical methods. Chapman and Hall Ltd., London; 1973: 49-188.

11. Dhayanithi NB and Balasubramaniyan KA. Effect of Excoecaria agallocha leaves against Aeromonas hydrophila in marine ornamental fish, Amphiprion sebae. Indian J Geo Marine Sci 2010; 41(1):76-82.

12. Kathiresan K. A review of studies on Pichavaram mangrove, southeast India. Hydrobiologia 2000; 430: 185-205.

13. Premanathan $M$, Arakaki $R$, Izumi $H$, Kathiresan $K$, Nakano M, Yamamoto $\mathrm{N}$, et al. Antiviral properties of a mangrove plant, Rhizophora apiculata Blume, against human immunodeficiency virus. Antivir Res 1999; 44:113-122.

14. Bandaranayake WM. Bioactivities, bioactive compounds and chemical constituents of mangrove plants. Wetlands Ecology and Management 2002; 10:421-452.

15. Ghani A. Medicinal Plants of Bangladesh, 2nd ed., The Asiatic Society of Bangladesh 2003; 228-229.

16. Peter KLN and Sivasothi NA. Guide to the Mangroves of Singapore I: The Ecosystem and Plant Diversity, Singapore Science Centre 1999:111-112.

\footnotetext{
Authors Contribution:

Am - Designed the experiments performed the laboratory tests and drafted the manuscript; SP - Analysed the data and drafted the manuscript; VK - Designed the study and reviewed the manuscript.

Source of Support: Nil, Conflict of Interest: None declared.
} 